\title{
EDMUND BURKE AND THE "PRESENT DISCONTENTS"
}

\author{
BY NANCY HARPER
}

Dr. Harper is an assistant professor of communication in Rutgers College

LEXANDER LIBRARY has recently acquired a I 775 edi-
tion of Edmund Burke's Thoughts on the Cause of the Present
Discontents.* The pamphlet, written for I 8 th century England, has surprising relevance for 2oth century America. It is of interest to students of practical decision-making for it demonstrates Burke's characteristically pragmatic approach to problem-solving. For literary and rhetorical critics, the pamphlet is a prime example of the I 8 th century's facility for combining eloquence with sound logical deduction. For historians, Present Discontents (along with Burke's speeches, On Conciliation and On American Taxation) is a goldmine of data on the events leading up to the American Revolution. For students of politics, the work represents the first attempt to set down the principles upon which the modern political party system is based. More importantly the pamphlet is relevant to all of us, whatever our special interests, who find ourselves involved in the "discontents" of Watergate. Present Discontents is primarily a manifesto against the usurpation of power by a single individual and an elite group of his chosen followers. It is an argument for open government and shared powers and, as such, it has much to offer to the debate now being carried on in the congress, in the courts, and on the public airways.

One of the primary issues facing Parliament in the I770's was the taxation of the American colonies. Burke's faction, the Rockingham Whigs, sought to reverse the policy of imposed taxation implemented by Grenville and others of the "king's men." Burke saw that, pragmatically, Britain could not force her will upon the colonies unless she was willing to engage in all-out war, thus destroying the very possibility of future revenue, whether voluntary or involuntary. He attributes Britain's difficulties with the colonies to "the injudicious

* 5 th Ed. (London, J. Dodsley, I775). 
tamperings of bold, improvident, and visionary ministers," like Grenville, who have lost all sight of the reality of current circumstances in America, who ignore all the lessons of experience in favor of $a$ priori assertions of "right." To Burke, the argument that Britain had a "right" to tax America was totally irrelevant in light of the fact that America refused to be taxed. As he explains, "politics ought to be adjusted, not to human reasonings [deductions from a priori principles], but to human nature; of which the reason is but a part, and by no means the greatest part."

This is the context, then, which gave rise to the pamphlet. In it Burke describes the causes of Britain's problems with America and offers his solution to these problems. However, the "discontents" of the title refers not only to dissension between America and Britain, but also to the internal wrangling occasioned by the taxation debate in Parliament and in the press. Thus the ultimate source of the problem and the best solution is, according to Burke primarily internal rather than external. The real problem, according to him, was the King's ambition to establish personal rule. He saw the King as attempting to usurp the powers of Parliament through the machinations of the "double cabinet," a small group of political courtiers close to the King who worked to pass the King's measures, thus subverting the independence of Parliament. The solution, he claims, is openly established political parties based on issues rather than on personal advantage - a consortium of "measures rather than men." He offers his own party as an example of this solution and distinguishes it from the current "factions," like the double cabinet, "who are combined for no public purpose, but only as a means of furthering with joint strength their private and individual advantage."

But if Burke's only solution to an overly ambitious chief executive and his elite clique were publicly declared political parties, then the Present Discontents would have little value for those of us involved in the discontents of I974. After all, we have such parties. But Burke goes on, in what might be considered a more philosophical vein, to analyze the relationships between the executive, legislative, and judicial branches of government and the people. It is in his analysis of the relationship between the government and the people that we today can find most relevance. 
Rather than summarize what are to us rather standard (though at the time radical) arguments in favor of checks and balances, I would like to cite some of the more significant points Burke makes about the reality, not the theory, of the function of representational government in civil society. For instance, near the beginning of the work, Burke outlines the principles upon which both his indictment of, and solutions to, the present state of affairs is based. He writes:

Nations are not primarily ruled by laws: less by violence. Whatever original energy may be supposed either in force or regulation, the operation of both is, in truth, merely instrumental. Nations are governed by the same methods, and on the same principles, by which an individual without authority is often able to govern those who are his equals or his superiors; by a knowledge of their temper, and by a judicious management of it; I mean-when public affairs are steadily and quietly conducted; not when government is nothing but a continued scuffle between the magistrate and the multitude; in which sometimes the one and sometimes the other is uppermost; in which they alternately yield and prevail, in a series of contemptible victories; and scandalous submissions. The temper of the people amongst whom he presides ought therefore to be the first study of a statesman (emphases mine).

In this statement Burke does not mean to suggest that a statesman should operate like an advertising agency, doing market research and giving the people what they want, whether or not it is good for them. He simply means that a people cannot be forced against its will through the simple expedient of making a law. As Burke explains it, if the people are determined that they will not be taxed in one manner, or on one class of goods, then no law can force them to submit. What the statesman must do is find another, less repugnant, source of revenue-assuming, of course, that revenue and not repression is the true objective. Those who insist that they have the "right" to make repugnant laws become so involved with defending their right that they forget the goal that they set out to achieve. Again Burke assures us that popular will is not always "right," but it is real and must be faced. Furthermore, "in all disputes between them and their rulers, the presumption is at least upon a par in favor of the people."

The remainder of the pamphlet is primarily an explication of this relationship between the people and their government. The recurring theme centers around the abuse of power by leaders who are ignorant of, or who ignore, the needs and will of those they represent. For 
instance, Burke sees the "cabal," the members of Parliament who have become the King's personal friends and who are loyal only to their own advantage, as most dangerous because of their contempt for the will of the people. He writes:

The point to be gained by the cabal was this; that a precedent should be established, tending to show, That the favor of the people was not so sure a road as the favor of the court [the king and his "men"] even to popular honors and popular trusts. A strenuous resistance to every appearance of lawless power; a spirit of independence carried to some degree of enthusiasm; an inquisitive character to discover, and a bold one to display, every corruption and every error of government; these are the qualities which recommend a man to a seat in the House of Commons, in open and merely popular elections. An indolent and submissive disposition; a disposition to think charitably of all the actions of men in power, and to live in mutual intercourse of favors with them; an inclination rather to countenance a strong use of authority, than to bear any sort of licentiousness on the part of the people; these are unfavorable qualities in an open election for members of Parliament.

In this statement Burke sums up the sources not only of the discontents of his time but also of those of our own. "My party (King, President, Country, etc.) right or wrong," is the motto which led to Watergate and which led, eventually, to war between Britain and her colonies. As Burke points out, loyalty, and voting behavior, based on personal attachments, on ambition for personal power, can lead only to despotism, for "the forms of a free, and the ends of an arbitrary government, [are] not altogether incompatible." When a strong man gathers around him a group of men who have "a disposition to think charitably" of all his actions, who are more devoted to his will than to justice and utility for their constituents, then despotism can exist and thrive within a democratic structure. The only way this undermining of free government can be prevented is through public scrutiny of the men who make policy, for as Burke points out:

Constitute government how you please, infinitely the greater part of it must depend upon the exercise of the powers which are left at large to the prudence and uprightness of ministers of state ... of all things, we ought to be the most concerned who, and what sort of men they are that hold the trust of everything that is dear to us.

As he goes on to say, "the people must on their part show themselves sensible of their own value," they must be aware of, and insist upon the exercise of, their right to observe the government in action. 
History shows, Burke reminds us, that "all men possessed of an uncontrolled discretionary power leading to the aggrandizement and profit of their own body have always abused it."

In addition to advocating the establishment of political parties based on publicly declared stands on the issues and publication of voting records, Burke urges the House to remember, and reclaim, its basic rights. Among these are its power of impeachment, its right to appoint its own officers (and the right of its appointed officers to carry out their duties without infringement from the crown), and most importantly its power to negate as well as approve executive proposals. It is this "control" function that Burke sees as most crucial to the operation of a free and representative government:

When ... the genuine dignity of the House of Commons is restored, it will begin to think of casting from it, with scorn, as badges of servility, all the false ornaments of illegal power, with which it has been, for some time, disgraced. It will begin to think of its old office of CONTROL. It will not suffer that last of evils to predominate in the country: men without popular confidence, public opinion, natural connection, or mutual trust, invested with all the powers of government.

This brief summary of Burke's observations on the role of government in a free society cannot do justice to the depth and strength of his arguments. For that only the whole of the work will serve. However, the few quotations cited above do provide a representative sample of the tendency of the whole. Those of us who, after the fact, have reached conclusions similar to Burke's on the dangers of the subordination of law and public duty to personal ambition and personal loyalty can but feel that more attention to the best thinking of the past might better have guided us in our attempt to live in the present and future. 